\title{
Anticancer Molecules from Catharanthus roseus
}

\author{
Zarani M. Taher ${ }^{1}$, Farid Agouillal'2,3, Lim J. $\mathbf{R}^{4}$, Aina Q. Marof ${ }^{5}$, Daniel Joe Dailin ${ }^{1,4}$, Muktiningsih \\ Nurjayadi $^{5}$, Ezzaty N.M Razif ${ }^{6}$, Sara E. Gomaa ${ }^{7}$ and Hesham A. El Enshasy ${ }^{1,4,8}$
}

1. Institute of Bioproduct Development (IBD), Universiti Teknologi Malaysia (UTM), Johor Bahru, Malaysia.

2. Research Unit on Analysis and Technological Development in Environment, URADTE, Centre de Recherche Scientifique et Technique en Analyses Physico-Chimiques, CRAPC, B.P. 384, RP 42004 Zone Industrielle Bou-Ismail, Tipaza, Algeria.

3. Laboratory of Reaction Engineering, LGR, Faculty of Mechanical Engineering and Process Engineering, Houari Boumediene University of Science and Technology, USTHB, PB 32 El Alia, 16075, Bab Ezzouar, Algiers, Algeria.

4. School of Chemical Engineering and Energy, Faculty of Engineering, Universiti Teknologi Malaysia (UTM), 81310 Johor Bahru, Malaysia.

5. Department of Chemistry, Mathematics and Science Faculty, Universitas Negeri Jakarta, Jakarta, Indonesia, Jl. Rawamangun Muka, Jakarta Timur, Daerah Khusus Ibukota Jakarta 13220

6. Faculty of Applied Sciences, Universiti Teknologi Mara Negeri Sembilan, Kampus Kuala Pilah, Pekan Parit Tinggi, Kuala Pilah Negeri Sembilan, Malaysia. 72000

7. Horticulture Research Institute, Agriculture Research Center, 9 ALgamaa Street, Giza, Egypt

8. Genetic Engineering and Biotechnology Research Institute, City of Scientific Research and Technology Applications (CSAT), New Burg Al Arab Alexandria, Egypt.

\begin{tabular}{l}
\hline Info Article \\
\hline Submitted: 24-02-2019 \\
Revised: 28-05-2019 \\
Accepted: 01-07-2019 \\
*Corresponding author \\
Hesham Ali El Enshasy \\
Email: \\
henshasy@ibd.utm.my
\end{tabular}

\begin{abstract}
Catharanthus roseus is an important medicinal plant found in various parts of the world and the bioactive compound has been extracted and used as anticancer agent to treat the cancer over decades. However, the extraction of bioactive compound also results in the generation of large quantities of pollution with wasted solvents. Toxic pollution occurs when synthetic chemicals are discharged or natural chemicals accumulate to toxic levels in the environment, causing reductions in wildlife numbers, degrading ecosystem functions and threatening human health. This review covers the extraction and phytochemical obtained leading to chemical compounds related to anti-cancer property of $C$. roseus. Additionally, recent advances of using biological cell cultures were also addressed. Thus, this work can be used for further investigation of $C$. roseus to be undertaken in future for its anticancer property further development and efficient production in drug industry.
\end{abstract}

Key words: C. roseus; Anticancer; Extraction; Phytochemical; Tissue culture

\section{INTRODUCTION}

Cancer is a disease that in which a group of abnormal cells grow uncontrollably beyond usual boundaries by disregarding the normal rules of cell division and causing a lump known as tumour. Tumour formed can then invade adjoining parts of the body and spread to other organs, this process is known as metastasis which is the major cause of death from cancer. According to the World Health Organization (WHO), cancer is the second leading cause of death globally; nearly 1 in 6 deaths is due to cancer. Cancer was responsible for 8.8 million deaths in 2015 and approximately $70 \%$ of deaths from cancer occur in low and middle income countries. In additional, according to Ministry of Health Malaysia, cancer is one of the fatal non-communicable diseases in Malaysia and contributed to $13.56 \%$ of all deaths in 2015 (Azizah et al., 2016). It was the third most common cause of death following diseases of circulatory system and respiratory system. C. roseus is a plant belonging to Apocynaceae family and the name Catharanthus comes from Greek word which means 'pure flower'. C. roseus is a perennial plant that commonly grows in tropical countries and Catharanthus is more known as Madagascar periwinkle. 

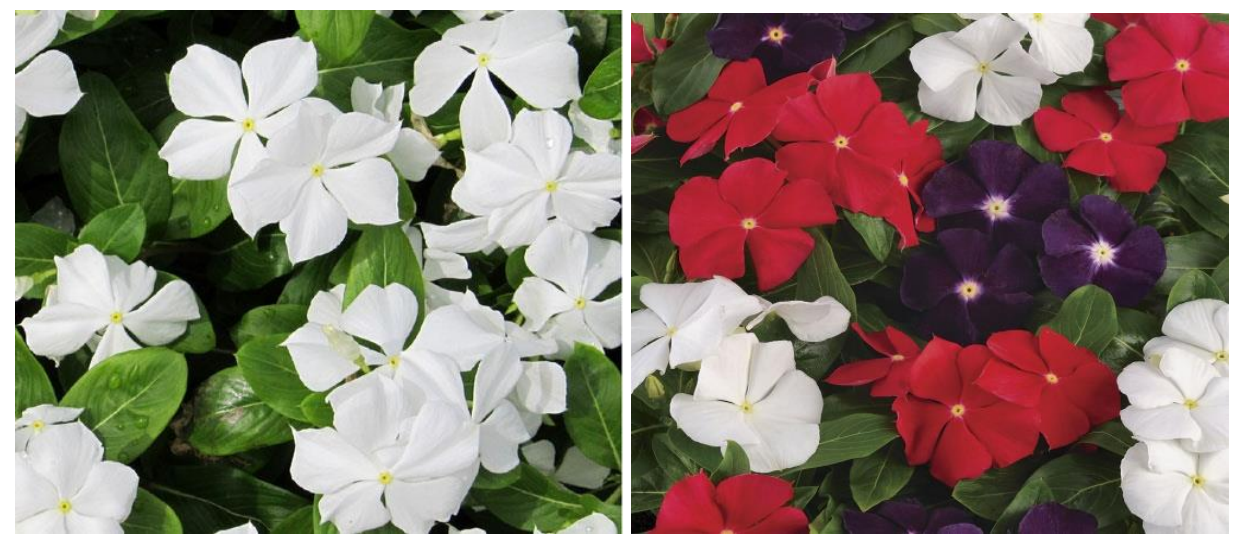

Figure 1 . The variety of $C$. roseus flowers.

C. roseus has long been cultivated for herbal medicine and also as an ornamental plant. In Indian and Chinese traditional medicine, the extracts have been used against numerous diseases such as malaria, diabetes and Hodgkin's disease. It has been reported that $C$. roseus contain more than 70 different types of chemical constituents such as indole type of alkaloids, ajmalicine, serpentine and reserpine (Kabesh et al., 2015). The Catharanthus alkaloids provide protection against microbial infection, abiotic environmental stresses such as UV irradiation and are wide importance in clinical medicine due to the anti-hypertensive and antispasmodic properties (Sain and Sharma, 2013; Nejat et al., 2015).

The Catharanthus alkaloids, vincristine and vinblastine which found abundantly in the leaves part of the plant inhibited the growth of tumour and hence contribute the anticancer property of $C$. roseus (Das and Sharangi, 2017). Vinblastine and vincristine were the first natural drugs used in cancer therapy and still among the most valuable agents used in cancer treatment (Costa et al., 2008). Vinblastine and vincristine are able to inhibit the cell mitotic and widely used medically to treat different kinds of cancers such as breast cancer, Hodgkin's lymphoma and leukemia. Vinblastine and vincristine bind to tubulin which is a structural protein that can be found in the cytoplasm, thereby inhibit the assembly of microtubule structures.

\section{GEOGRAPHIC DISTRIBUTION OF C. Roseus}

C. roseus is a tropical or subtropical plant which belongs to the family of Apocynaceae and known as Madagascar periwinkle. The origin of the C. roseus is in Madagascar. The plant is used for the medical and decorative in many countries such as Malaysia (Ong et al., 2011), India, China, South Africa and Mexico (Patel et al., 2012). It is incorporates a high salt tolerance which up to 2000 ppm and typically found close to water level where somewhat higher altitudes. C. roseus can grow 20$60 \mathrm{~cm}$ high and wide and it also had variety color of flower such as pink, white or rosy-purple. The flowers are pollinated by butterfly and it selffertilized. It has a basal tube which $2.5-3.0 \mathrm{~cm}$ long with a corolla about $2.0-5.0 \mathrm{~cm}$ diameter. It has five sepals which $2-6 \mathrm{~mm}$ long, narrow and with hairs. Besides that, the leaves are oppositely arranged on the stem with leaf margin and have pinnate venation structure. The length of the blade is about 2-4 inches. The fruit pod found to be a pair of a follicle of about 2.0-4.5 $\mathrm{cm}$ long and $3 \mathrm{~mm}$ wide whereas the fruit characteristic invisible.

\section{MEDICINAL USES OF $C$. Roseus}

Since the ancient time, people had been used this plant as one of the medication alternative for various diseases. In most country, C. roseus was used for cancer treatment as it is one of the plants that produced phytochemical that fights cancer. In India, people had been used the leaf extract in order to cure bee sting or wasp sting. Other than that, in the decoction of the leaves was used for diabetes (Nammi et al., 2003). The Philippines and African people use the leaf infusion for menorrhagia. The raw extracts of the leaves and roots were used to treat cancer activity and severe diarrhea. In Mauritius, the extract used for dyspepsia. The people in the Bahamas used the flower decoction to treat asthma, tuberculosis, and flatulence. In Malaysia, West Indie and Nigeria the plant was used to treat diabetes. 
Following that, people in Madagascar used the leaf as evoke vomiting while in Hawaii the extraction was used to arrest bleeding (Sharangi, 2017).

\section{EXTRACTION METHODS AND PHYSICO- CHEMICAL ANALYSIS OF ANTI-CANCER MOLECULES FROM $C$. Roseus}

Chemical solvents that used for bioactive compound extraction might lead to environmental pollution. Long term exposure to the hazardous solvent waste from many industrial processes can lead to deleterious effect on respiratory, haematological and thyroid functioning (Babu and Reddy, 2014). The extraction conducted by using water as the solvents is an alternative method to extract the bioactive compound. However, in water extraction method, high temperature of water is required to extract the compound. The increase in temperature during extraction might deteriorate the quality of extract and degrade the desired bioactive compound. Moreover, water extraction method required a long time in order to complete the extraction process (Wojdylo et al., 2013).

C. roseus produces low levels of two dimeric terpenoid indole alkaloids, vinblastine and vincristine, which are widely used in cancer chemotherapy (Costa et al., 2008). The extraction and purification of several alkaloids found in C. roseus was first developed by Eli Lilly in the 1970s using organic solvents methods (Falcao et al., 2017). These extraction methods using water with sulphuric acid includes four steps such as fractionation by partition with benzene, two chromatographic columns, crystallization in ethanol and sulphuric acid. Extraction of vindoline, catharanthin, and vinblastine from $C$. roseus leaves has been extensively carried out using ultrasound extraction with dilute or methanol as solvent, heating, boiling and refluxing with methanol. Additionally, several researches have been reported the used of supercritical fluid extraction (SFE) to extract phytochemical from $C$. roseus a (Verma et al., 2008; Falcao et al., 2017). Several phytochemical compounds obtained from $C$. roseus using advances technology to develop anti-cancer property (Table I).

\section{CHEMICAL COMPOSITION, STRUCTURE AND MODE OF ACTION OF ANTICANCER MOLECULES OF C. Roseus}

C. roseus produce several indole alkaloids, named as Vinka alkaloids, which is widely used as antimitotic drugs in the treatment of cancer
(Almagro et al., 2015). This includes natural products like vincristine and vinblastine, the first anticancer agents used clinically (Sottomayor et al., 2005) and their semisynthetic derivatives like vindesine, vinorelbine and vinflunine (Van der Heijden et al., 2004; Moudi et al., 2013). In comparison with vinblastine structure, the velbanamine moiety characterize vinflunine and vinorelbine which are both synthesized from the precursor alkaloids catharanthine and vindoline to increase their therapeutic action (Nirmala et al., 2011; Ngan et al., 2000).

Vinca alkaloids provoke apoptosis and cell growth repression by altering the microtubular dynamics. These Microtubules (MTs) are components of the cytoskeleton which are the major constituents of mitotic spindles involved in chromosome separation during meiosis and mitosis, they are also involved in maintaining cell structure, transport and many others cellular processes (Wang et al., 2012; van der Heijden et al., 2004). The basic units of the MTs are $\alpha$-tubulin and $\beta$-tubulin heterodimers which are in a dynamic polymerization and depolymerization at their ends; this assembly and disassembly of the MT polymers, also called as "treadmilling" and "dynamic instability", is regulated by the binding of tubulin and guanosine 5-triphosphate (GTP), then, any destabilization or interruption of this dynamics can arrest the cell cycle and lead to programmed cell death or apoptosis (Jordan et al., 2002). Since, two groups of destabilizers are distinguished; the first group compounds are the MT-stabilizing agents that prevent the depolymerization and the second group compounds are MT-depolymerizing agents that inhibit MTs assembly (Perez et al., 2009; Islam and Iskander, 2004).

To arrest tumour cells cycle during mitosis, Vinca alkaloids and their derivatives act by binding at the surface between two tubulin heterodimers next to the exchangeable GTP-binding site and depolymerizing the MTs (Morris and Fornier, 2008; Bolanos-Garcia, 2009). The affinity of both natural Vinca alkaloids from $C$. roseus or their semisynthetic analogues and derivatives for tubulin heterodimers appears to be the same but it is characterized by the decrease of the overall equilibrium constants as following order: vincristine $>$ vinblastine $>$ vinorelbine $>$ vinflunine (Gigant et al., 2005; Okouneva et al., 2003). The complexes of these alkaloids with $\alpha, \beta$-tubulin are stabilized by van der Waals forces and electrostatic interaction energy through common binding site. 
Table I. Phytochemicals extracts and fractions obtained from C. roseus

\begin{tabular}{|c|c|c|c|}
\hline No. & Bioactive Phytochemicals & Extraction/determination method & References \\
\hline 1 & $\begin{array}{l}\text { Vindoline, vinblastine, catharanthine, } \\
\text { vincristine }\end{array}$ & Ultraviolet-c treated CMCs extraction & Moon et al., 2018 \\
\hline 2 & $\begin{array}{l}\text { Vincristine, vinblastine, ajmalicine, } \\
\text { catharanthine, serpentine, vindoline }\end{array}$ & $\begin{array}{l}\text { Ultra HPLC-quadrupole time-of-flight } \\
\text { (UPLC-Q-TOF) mass spectrometry method }\end{array}$ & Jeong et al., 2018 \\
\hline 3 & Vinblastine, vincristine & $\begin{array}{l}\text { Modular transcriptional control of MIA } \\
\text { (monoterpoid indole alkaloid) } \\
\text { biosynthesis }\end{array}$ & $\begin{array}{l}\text { Schweizer } \text { et al., } \\
2018\end{array}$ \\
\hline 4 & $\begin{array}{l}\text { Vincristine, vinblastine, vindesine, } \\
\text { ajmalicine, ajmaline, reserpine, } \\
\text { vindoline }\end{array}$ & Ultra HPLC - tandem mass spectrometry & $\begin{array}{l}\text { Kumar et al., } \\
2018\end{array}$ \\
\hline 5 & Vinblastine, vincristine & Yeast extract elicitation & $\begin{array}{l}\text { Maqsood et al., } \\
2017\end{array}$ \\
\hline 6 & $\begin{array}{l}\text { Catharanthine, vinblastine, } \\
\text { vincristine, vindoline }\end{array}$ & $\begin{array}{l}\text { HPLC and qualification reverse - } \\
\text { transcription polymerase chain reaction } \\
\text { qRT-PCR, ultraviolet-C }\end{array}$ & Moon et al.,2017 \\
\hline 7 & $\begin{array}{l}\text { Vincristine, } \\
\text { vinblastine, } \\
\text { Vindoline, } \\
\text { catharanthine, yohimbine }\end{array}$ & $\begin{array}{l}\text { HPLC with diode array detector } \\
\text { (HPLC-DAD) }\end{array}$ & Liu et al., 2016 \\
\hline 8 & Catharanthine and vindoline & Centrifugal partition chromatography & $\begin{array}{l}\text { Kotland et al., } \\
2016\end{array}$ \\
\hline 9 & $\begin{array}{l}\text { Cathacunine, dimeric indole } \\
\text { alkaloids }\end{array}$ & $\begin{array}{l}\text { Nuclear factor kappa-light chain-enhancer } \\
\text { of activated B cells }\left(N F_{K} B\right) \text { and c-jun } \mathrm{N} \\
\text { terminal kinase (JNK), HPLC }\end{array}$ & Wang et al., 2016 \\
\hline 10 & $\begin{array}{l}\text { Ajmalicine, Serpentine, } \\
\text { Catharanthine, vindoline, } \\
\text { vindolinine, vincristine, vinblastine, } \\
\text { anhydrovinblastine }\end{array}$ & $\begin{array}{l}\text { HPLC -DAD method simultaneous analysis } \\
\text { of terpenoid indole alkaloids(TIAs) }\end{array}$ & Pan et al., 2016 \\
\hline 11 & $\begin{array}{l}\text { Vincristine, vinblastine and } \\
\text { catharanthine }\end{array}$ & Agilent HPLC, C18 column, HPLC with UV & $\begin{array}{l}\text { Hanafy et al., } \\
2016\end{array}$ \\
\hline 12 & $\begin{array}{l}\text { Vindogentianine, } \\
\text { Vindoline, vindolidine, vindolinine, } \\
\text { vindolicine, serpentine and perivine }\end{array}$ & NMR, MS, UV and IR & Tiong et al., 2015 \\
\hline
\end{tabular}

Also, this electrostatic interaction is improved in the case of vinflunine probably due to its two fluorine atoms that differentiate it from vinorelbine (Coderch et al., 2012; Miyamoto et al., 2003), then, tubulin heterodimers binding is ensured by the vindoline domain, while the cytotoxic effect is provided by the catharanthine domain (Sertel et al., 2011). Several authors have reported that Vinca alkaloids acts following dose-dependent model leading to stop the cell mitosis when the levels of Vinca alkaloids are low, then, the cells die after a long time of incubation. However, at high concentration, Vinca alkaloids stop the mitosis of the tumoral cells by the formation of paracristals (large tubulin polymers) and immediately provoke the cell death (Takanari et al., 1990; Attard et al., 2006). New mechanisms of action of these alkaloids have been recently reported by many authors, then, they can interplay with MTs associated protein, they can interact with calmodulin and they can inhibit the amino acid metabolism (Barbier et al., 2013; Schutz et al., 2011). However, differences of Vinca alkaloids activity were observed with this new mode of action. Then, the better efficacy of vinflunine in comparison with vinblastine against murine tumours and human tumour xenografts can be explained by its interaction with calmodulin in spite of its lower binds to tubulin than vinblastine or vincristine (Van der Heijden etal., 2004; Almagro etal., 2015). 


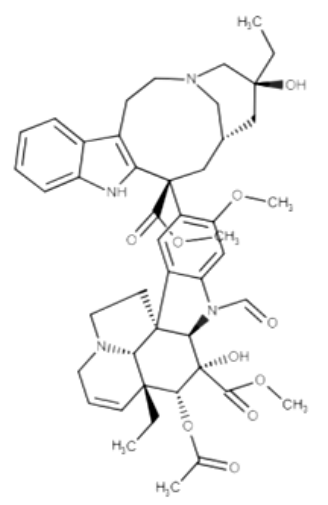

Vincristine

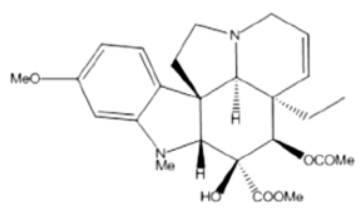

Vindoline

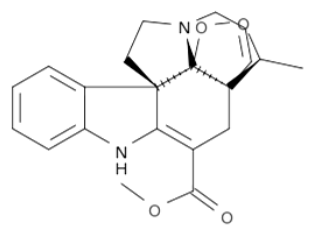

Catharoseumine

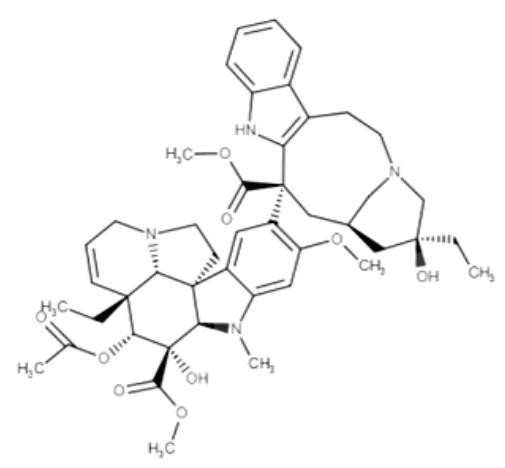

Vinblastine

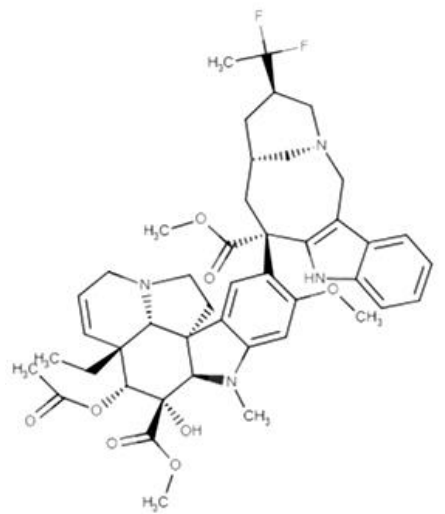

Vinflunine

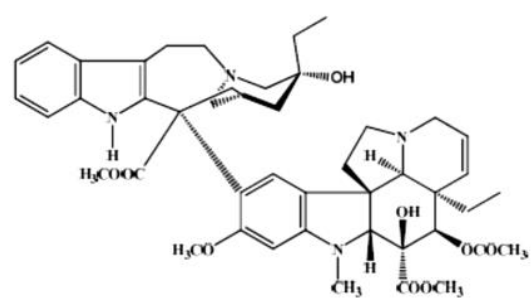

Vinposidin

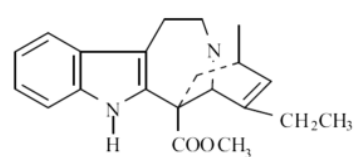

Catharanthine

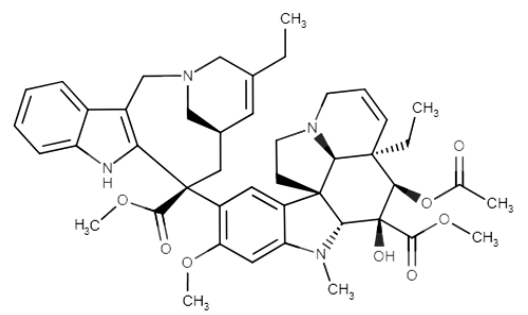

Vinorelbine

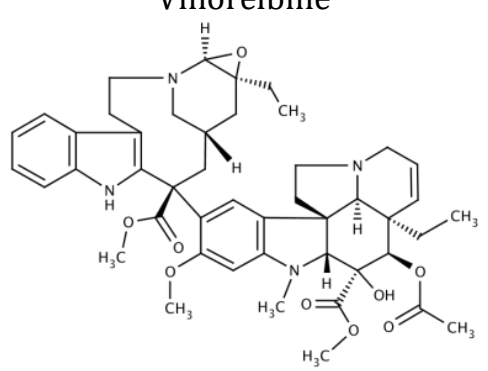

Vinleurosin

Figure 2. Chemical Structure of main bioactive alkaloids from C. roseus Vinca alkaloids.

Other indole alkaloids from $C$. roseus were reported as cell growth inhibitors. However, their mechanism of action is still not well-known. Catharoseumine, the monoterpenoid indole alkaloid isolated from $C$. roseus by Wang et al. (2012), possess a unique peroxy bridge moiety and show cytotoxic effect when tested in human tumour cell lines but only a moderate cytotoxic effect against HL-60 cell line. In 1974, Eli Lilly Company has patented a preparation process of vinposidin (Leurosidin) used as an antimitotic agent (Eli Lilly, 1974; Keglevich et al., 2012) (Table II).

\section{PRODUCTION OF ANTICANCER COMPOUNDS OF C. Rose us INSUBMERGED CULTURE SYSTEM}

Beside the conventional approach of using grown plant in the field as initial materials of the production of anticancer compound of $C$. roseus, during the recent years many research have been focused on the cultivation of plant cells for more efficient production of anticancer compound. This method of cultivation offer many advantages such as: reducing the number of purification steps, highly efficient production system in shorter time, and well controlled production 
Table III. Alkaloids from C. roseus used as antimitotic drugs.

\begin{tabular}{|c|c|c|c|}
\hline \multirow{3}{*}{$\begin{array}{l}\text { Molecules } \\
\text { Vincristine } \\
\text { (Oncovin) }\end{array}$} & Cancer Type Targeted & In vitro / in vivo testing & Reference \\
\hline & Leukaemia & $\begin{array}{l}\text { HL60 human acute } \\
\text { promyelocytic leukemia cells, } \\
\text { K562 human chronic } \\
\text { myelogenous leukemia cells } \\
\text { and EA.hy926 human } \\
\text { umbilical vein cells }\end{array}$ & Wang et al., 2016 \\
\hline & Lymphomas & B-cell lymphoma cell line & Qiu et al., 2018 \\
\hline $\begin{array}{l}\text { Vinblastine } \\
\text { (Velban) }\end{array}$ & Leukimia & $\begin{array}{l}\text { Chronic Lymphocytic } \\
\text { Leukaemia (CLL) }\end{array}$ & Bates et al., 2014 \\
\hline Vinorelbine, & Solid tumours & Clinical trials & Bahleda et al., 2018 \\
\hline (Navelbine) & $\begin{array}{l}\text { Breast cancer } \\
\text { Non-Small-Cell Lung cancer }\end{array}$ & $\begin{array}{l}\text { Clinical trials } \\
\text { Clinical trials }\end{array}$ & $\begin{array}{l}\text { Nazir et al., } 2016 \\
\text { Nazir et al., } 2016\end{array}$ \\
\hline Vinflunine & $\begin{array}{l}\text { Non-Small-Cell Lung cancer } \\
\text { Urothelial carcinoma }\end{array}$ & $\begin{array}{l}\text { C } \\
\text { Human patients }\end{array}$ & $\begin{array}{l}\text { Krzakowski et al., } 2010 \\
\text { Schinzari et al., } 2018\end{array}$ \\
\hline Catharanthine & Colorectal Carcinoma & $\begin{array}{l}\text { Human Colorectal Carcinoma } \\
\text { Cell Line (HCT 116). }\end{array}$ & Siddiqui et al, 2010 \\
\hline Cathachunine & Leukemia & $\begin{array}{l}\text { B cells (NF- } \kappa \mathrm{B} \text { ) and c-Jun } N- \\
\text { terminal kinase (JNK) } \\
\text { pathways }\end{array}$ & Wang et al., 2016 \\
\hline
\end{tabular}

process under sterile conditions to cope with the cGMP requirements for the production of bioactive drugs. Therefore, in recent years production of high value medicinal product by $C$. rosesus is carried out in submerged cultivation systems either using shake flask or different types of bioreactors (Ducos et al., 2009; Mujib et al., 2014). Bioreactors of different scales have been proven to be suitable for the cultivation of hairy root lines of $C$. roseus for large scale production of ajmalicine, serpentine, and catharanthine (Verma et al., 2012). Other anticancer bioactives such as vincristine and vinbalastine were successfully produced in stirred tank bioreactor. The maximal production of these alkaloid is carried out under uncontrolled $\mathrm{pH}$ and aeration rate of $0.5 \mathrm{v} / \mathrm{v} / \mathrm{min}$. The alkaloid production was 13.47 and 7.94 folds higher compared to intact plant for vincristine and vinblastine, respectively (Taha et al., 2014). However, addition of chemical to induce stress on cells can increase also the alkaloid compound production. It has been reported that addition of chromium to culture medium in very low concentration (in range between 10-100 $\mu \mathrm{M}$ ) reduced cell growth concomitant with a significant increase in vinblastine and vincristine production (Rai et al., 2014). Addition of sodium chloride to increase osmotic stress in culture can lead also to various stress signalling, enzyme activities and increase both of vinblastine and vincristine production as well (Fatima et al., 2015). Other study also reported that the addition of fungus elicitor of Aspergillus flavus lead to a significant stimulation of cell growth and increase in both vinblastine and vincristine production (Tonk et al., 2016). Recent research reported on the positive effect of yeast extract supplementation to culture medium on increasing the vinblastine and vincristine when added in concentration as low as $1.5 \mathrm{~g} / \mathrm{L}$ in suspension culture of C. roseus (Maqsood and Abdul, 2017).

\section{CONCLUSION}

During recent years, the demand for natural bioactive compounds have been increased as alternative or in combination with chemo- and radiotherapy in cancer treatment to reduce their side effects. Based on many years research, $C$. roseus is considered as one of the plant biofactory for the production of highly potent anticancer molecules. Of different compounds studied, vincristine and vinblastine are the widely used compounds in pharmaceutical industries. However, other molecules such as cathachunine, catharanthine, vinflunine, and vinorelbine have also high potential application as anticancer compound based on many in vivo and in vitro studies. The most attractive features of this plant is 
the ability to cultivate in submerged culture using bioreactors. This make it easy to cultivate and production of the anticancer compounds in high concentration, in shorter time, and under fully sterile condition with full compliance with cGMP for drug manufacturing.

\section{ACKNOWLEDGEMENT}

The authors would like to express their sincere acknowledgment the support of MOE and UTM-RMC (Malaysia) through HICOE grant no. R.J130000.7846.4J262.

\section{REFERENCES}

Almagro L., Fernández-Pérez F. and Pedreño MA. 2015. Indole alkaloids from Catharanthus roseus: bioproduction and their effect on human health. Molecules. 20(2): 2973-3000.

Attard G., Greystoke A., Kaye S. and De Bono J. 2006. Update on tubulin-binding agents. Pathologie Biologie. 54(2): 72-84.

Azizah AM., Saleha NIT., Hashimah NA., Asmah Z., Mastulu W. 2016. Malaysian National Cancer Registry Report 2007-2011: Malaysia Cancer Statistic, Data and Figure. Malaysia: National Cancer Institute.

Babu NS., Reddy SM. 2014. Impact of solvents leading to environmental pollution. Journal of Chemical and Pharmaceutical Sciences. Special issue 3, 132-35

Bahleda R., Varga A., Bergé Y., Soria JC., Schnell D, Tschoepe I., Delord JP. 2018. Phase I openlabel study of afatinib plus vinorelbine in patients with solid tumours overexpressing EGFR and/or HER2. British Journal of Cancer. 118(3): 344-52.

Barbier P., Tsvetkov PO, Breuzard G., Devred F. 2014. Deciphering the molecular mechanisms of anti-tubulin plant derived drugs. Phytochemistry Reviews. 13(1): 157169.

Bates DJ., Danilov AV., Lowrey CH., Eastman A. 2013. Vinblastine rapidly induces NOXA and acutely sensitizes primary chronic lymphocytic leukemia cells to ABT-737. Molecular Cancer Therapeutics. 12(8): 150414.

Bolanos-Garcia VM. 2009. Assessment of the mitotic spindle assembly checkpoint (SAC) as the target of anticancer therapies. Current Cancer Drug Targets. 9(2): 131-41.

Coderch C., Morreale A., Gago F. 2012. Tubulinbased structure-affinity relationships for antimitotic Vinca alkaloids. Anti-Cancer
Agents in Medicinal Chemistry (Formerly Current Medicinal Chemistry-Anti-Cancer Agents). 12(3): 219-25.

Costa MMR., Hilliou F., Duarte P., Pereira LG., Almeida I., Leech M., Sottomayor M. 2008. Molecular cloning and characterization of a vacuolar class III peroxidase involved in the metabolism of anticancer alkaloids in Catharanthus roseus. Plant Physiology. 146(2): 403-17.

Das S., Sharangi AB. 2017. Madagascar periwinkle (Catharanthus roseus L.): Diverse medicinal and therapeutic benefits to humankind. Journal of Pharmacognosy and Phytochemistry. 6(5): 1695-701.

Ducos J-P., Terrier B., Courois D. 2009. Disposable bioreactors for plant micropropagation and mass plant cell culture. Advances in Biochemical Engineering and Biotechnology. 115: 89-115.

Eli Lilly Company, Neue Aminderivate von Vinblastin, Leurosidin und Leurocristin und Verfahren zu ihrer Herstellung (1974. DE Patent 22415980, 1974; Chemistry Abstract. 82, 579967b.

Falcao MA., Scopel R., Almeida RN., do Espirito Santo AT., Franceschini G., Garcez JJ. and Cassel E. 2017. Supercritical fluid extraction of vinblastine from Catharanthus roseus. The Journal of Supercritical Fluids. 129: 9-15.

Fatima S., Mujib A. and Tonk D. 2015. NaCl amendment improves vinblastine and vincristine synthesis in Catharanthus roseus: a case of stress signalling as evidence by antioxidant enzymes activities. Plant Cell, Tissue and Organ Culture (PCTOC). 121(2): 445-458.

Gigant B., Wang C., Ravelli RB., Roussi F., Steinmetz MO. and Curmi PA. 2005. Structural basis for the regulation of tubulin by vinblastine. Nature. 435(7041): 519.

Hanafy MS., Matter MA., Asker MS. and Rady MR. 2016. Production of indole alkaloids in hairy root cultures of Catharanthus roseus L. and their antimicrobial activity. South African Journal of Botany. 105: 9-18.

Islam M., Iskander MN. 2004. Microtubulin binding sites as target for developing anticancer agents. Mini Reviews in Medicinal Chemistry. 4(10): 1077-104.

Jeong WT., Lim HB. 2018. A UPLC-ESI-Q-TOF method for rapid and reliable identification and quantification of major indole alkaloids 
in Catharanthus roseus. J. Chromatography $B$. 1080: 27-36.

Jordan MA., Wilson L. 2004. Microtubules as a target for anticancer drugs. Nature Reviews Cancer. 4(4): 253-65.

Jordan MA. 2002. Mechanism of action of antitumor drugs that interact with microtubules and tubulin. Current Medicinal Chemistry-AntiCancer Agents. 2(1): 1-17.

Kabesh K, Senthilkumar P, Ragunathan R, Kumar RR. (2015). Phytochemical analysis of Catharanthus roseus plant extract and its antimicrobial activity. Int. Journal of Pure and Applied Bioscience. 3(2): 162-72.

Keglevich P., Hazai L., Kalaus G. and Szántay C. 2012. Modifications on the basic skeletons of vinblastine and vincristine. Molecules. 17(5): 5893-914.

Kotland A., Chollet S., Diard C., Autret JM., Meucci J., Renault JH and Marchal L. 2016. Industrial case study on alkaloids purification by $\mathrm{pH}$ zone refining centrifugal partition chromatography. Journal of Chromatography A. 1474: 59-70.

Krzakowski M., Ramlau R., Jassem J., Szczesna A., Zatloukal P. and Von Pawel J. et al., 2010. Phase III trial comparing vinflunine with docetaxel in second-line advanced nonsmall-cell lung cancer previously treated with platinum-containing chemotherapy. Journal of Clinical Oncology. 28(13): 2167173.

Kumar S., Singh A., Kumar B., Singh B., Bahadur L. and Lal M. 2018. Simultaneous quantitative determination of bioactive terpene indole alkaloids in ethanolic extracts of Catharanthus roseus (L.) G. Don by ultrahigh performance liquid chromatographytandem mass spectrometry. J. Pharm. and Biomedical Analysis. 151: 32-41.

Liu Z., Wu HL., Li Y., Gu HW., Yin XL., Xie LX. And Yu RQ. 2016. Rapid and simultaneous determination of five Vinca alkaloids in Catharanthus roseus and human serum using trilinear component modeling of liquid chromatography-diode array detection data. Journal of Chromatography B. 1026: 114-23.

Maqsood M. and Abdul M. 2017. Yeast extract elicitation increases vinblastine and vincristine yield in protoplast derived tissues and plantlets in Catharanthus roseus. Revista Brasileira de Farmacognosia. 27(5): 549-56.
Miyamoto DT., Perlman ZE., Mitchison TJ. and Shirasu-Hiza M. 2003. Dynamics of the mitotic spindle-potential therapeutic targets. Progress in Cell Cycle Research. 5:349-60.

Moon SH., Mistry B., Kim DH. and Pandurangan M. 2017. Antioxidant and anticancer potential of bioactive compounds following UV-C light-induced plant cambium meristematic cell cultures. Industrial Crops and Products. 109: 762-72.

Morris PG. and Fornier MN. 2008. Microtubule active agents: beyond the taxane frontier. Clinical Cancer Research. 14(22): 7167-72.

Moudi M., Go R., Yien CYS., Nazre M. 2013. Vinca alkaloids. Int. J. Preventive Medicine. 4(11): 1231.

Mujib A., Ali M., Isah T., Dipti. 2014. Somatic embryo mediated mass production of Catharanthus roseus in culture vessel (bioreactor) - A comparative study. Saudi Journal of Biological Sciences. 21: 442-49.

Nammi S, Boini MK, Lodagala SD, Behara RBS. 2003. The juice of fresh leaves of Catharanthus roseus Linn. reduces blood glucose in normal and alloxan diabetic rabbits. $B M C$ Complementary and Alternative Medicine. 3(1): 4.

Nazir T., Taha N., Islam A., Abraham S., Mahmood A. and Mustafa M. 2016. Monocytopenia; Induction by vinorelbine, cisplatin and doxorubicin in breast, non-small cell lung and cervix cancer patients. International Journal of Health Sciences. 10(4): 542-47.

Nejat N., Valdiani A., Cahill D., Tan Y-H., Maziah M. and Abiri R. 2015. Ornamental exterior versus therapeutic interior of Madagascar Periwinkle (Catharanthus roseus): The two faces of a versatile herb. The Scientific World Journal. V 2015, Article ID 982412.

Ngan VK., Bellman K., Panda D., Hill BT., Jordan MA. and Wilson L. 2000) Novel actions of the antitumor drugs vinflunine and vinorelbine on microtubules. Cancer Research. 60(18): 5045-051.

Nirmala MJ., Samundeeswari A. and Sankar PD. 2011. Natural plant resources in anti-cancer therapy-A review. Research in Plant Biology. 1(3).1-14

Okouneva T., Hill BT., Wilson L. and Jordan MA. 2003. The effects of vinflunine, vinorelbine, and vinblastine on centromere dynamics. Molecular Cancer Therapy. 2: 427-36. 
Ong HC., Ahmad N. Milow P. 2011. Traditional medicinal plants used by the temuan villagers in Kampung Tering, Negeri Sembilan, Malaysia. Studies on EthnoMedicine. 5(3): 169-73.

Pan Q., Saiman MZ., Mustafa NR., Verpoorte R. and Tang K. 2016. A simple and rapid HPLC-DAD method for simultaneously monitoring the accumulation of alkaloids and precursors in different parts and different developmental stages of Catharanthus roseus plants. Journal of Chromatography B. 1014: 10-16.

Patel DK., Kumar R., Laloo D. and Hemalatha S. 2012. Natural medicines from plant source used for therapy of diabetes mellitus: an overview of its pharmacological aspects. Asian Pacific Journal and Tropical. 2(3): 23950.

Perez EA. 2009. Microtubule inhibitors: Differentiating tubulin-inhibiting agents based on mechanisms of action, clinical activity, and resistance. Molecular Cancer Therapeutics. 8: 2086-95.

Qiu L., Dong C. and Kan X. 2018. lymphomatargeted treatment using a folic aciddecorated vincristine-loaded drug delivery system. Drug design, Development and Therapy. 12: 863-72.

Rai V., Tandon PK. and Khaltoon S. 2014. Effect of chromium on antioxidant potential of Catharanthus roseus varieties and production of their anticancer alkaloids: vincristine and vinblastine. BioMed Research International. Vol2014, Article ID 934182, $10 \mathrm{p}$.

Sain M. and Sharma V. 2013. Catharanthus roseus (An anti-cancerous drug yielding plant) - A review of potential therapeutic properties. International Journal of Pure and Applied Bioscience. 1: 139-42.

Schinzari G., Rossi E, Pierconti F., Garufi G., Monterisi S. et al., 2018. Monoinstitutional real world experience in management of Vinflunine as second line therapy for transitional cell carcinoma of the urothelium. Oncotarget, 9(9): 8765.

Schutz FA, Bellmunt J, Rosenberg JE, Choueiri TK. (2011). Vinflunine: drug safety evaluation of this novel synthetic Vinca alkaloid. Expert Opinion On Drug Safety. 10(4): 645-53.

Schweizer F., Colinas M., Pollier J., Van Moerkercke A., Bossche RV., de Clercq R. and Goossens A. 2018. An engineered combinatorial module of transcription factors boosts production of monoterpenoid indole alkaloids in Catharanthus roseus. Metabolic Engineering. $48: 150-62$.

Sertel S., Fu Y., Zu Y., Rebacz B., Konkimalla B., Plinkert PK. and Efferth T. 2011. Molecular docking and pharmacogenomics of Vinca alkaloids and their monomeric precursors, vindoline and catharanthine. Biochemical Pharmacology. 81(6): 723-35.

Sharangi SD. 2017. Madagascar Periwinkle ( $C$. roseus L.): Diverse medicinal and therapeutic benefits to humankind. J Pharmacognosy and Phytochemistry. 16951701.

Siddiqui MJ., Ismail Z., Aisha AFA. and Majid AM. 2010. Cytotoxic activity of Catharanthus roseus (Apocynaceae) crude extracts and pure compounds against human colorectal carcinoma cell line. International Journal of Pharmacology. 6(1), 43-7.

Sottomayor M, Ros Barcelo A. 2005.The Vinca alkaloids: from biosynthesis and accumulation in plant cells, to uptake, activity and metabolism in animal cells. In: Attaur R., editor. Studies in natural products chemistry (Bioactive natural products). Amsterdam: Elsevier Science Publisher. 81357.

Taha HS., Shamas KA., Nazif NM., Seif El-Nasr MM 2014. In vitro studies on egyptian $C$. roseus (L.) G.Don V: Impact of stirred reactor physical factors on achievement of cells proliferation and vincristine and vinblastine accumulation. Research J.Pharmaceutical, Biological and Chemical Sciences. 5: 330-40.

Takanari H., Yosida T., Morita J., Izutsu K. and Ito T. 1990. Instability of pleomorphic tubulin paracrystals artificially induced by Vinca alkaloids in tissue-cultured cells. Biology of the Cell. 70(1-2): 83-90.

Tiong SH, Looi CY, Arya A, Wong WF, Hazni H, Mustafa MR, Awang K. (2015). Vindogentianine, a hypoglycemic alkaloid from C. roseus (L.) G. Don (Apocynaceae). Fitoterapia. 102: 182-88.

Tonk D., Mujin A., Maqsood M., Ali M. and Zafar N. 2016. Aspergillus flavus fungus elicitation improves vincristine and vinblastine yield by augmenting callus biomass growth in Catharanthus roseus. Plant Cell, Tissue and Organ Culture (PCTOC). 126(2): 291-303.

Van der Heijden R., Jacobs DI., Snoeijer W., Hallard D. and Verpoorte R. 2004. The Catharanthus 
alkaloids: pharmacognosy and biotechnology. Current Medicinal Chemistry. 11(5): 607-28.

Verma A., Hartonen K. and Riekkola ML. 2008. Optimisation of supercritical fluid extraction of indole alkaloids from Catharanthus roseus using experimental design methodology-comparison with other extraction techniques. Phytochemical Analysis: An International Journal of Plant Chemical and Biochemical Techniques. 19(1): 52-63.

Verma P., Mathur AK. and Shanker K. 2012. Growth, alkaloid production, rol genes integration, bioreactor up-scaling and plant regeneration studies in hairy root lines of Cathranthus roseus. Plant Biosystems - An International Journal Dealing with all Aspects of Plant Biology. 146: 27-40.

Wang CH., Wang GC., Wang Y., Zhang XQ., Huang XJ., et al., 2012. Cytotoxic dimeric indole alkaloids from Catharanthus roseus. Fitoterapia. 83(4): 765-69.
Wang L., He HP., Di YT., Zhang Y. and Hao XJ. 2012. Catharoseumine, a new monoterpenoid indole alkaloid possessing a peroxy bridge from Catharanthus roseus. Tetrahedron Letters. 53(13), 1576-1578.

Wang XD., Li CY., Jiang MM., Li D., Wen P., Song X. et al., 2016. Induction of apoptosis in human leukemia cells through an intrinsic pathway by cathachunine, a unique alkaloid isolated from Catharanthus roseus. Phytomedicine. 23(6): 641-53.

Wojdylo A., Oszmiański J., Teleszko M. and SokółŁętowska A. 2013. Composition and quantification of major polyphenolic compounds, antioxidant activity and colour properties of quince and mixed quince jams. Int. J.Food Sciences and Nutrition. 64(6): 74956.

World Health Organization. Global Health Observatory. Geneva: World Health Organization; 2018. who.int/gho/ database/en/. Accessed July 20, 2018. 